\title{
KARAKTERISTIK INFEKSI SALURAN KEMIH PADA ANAK USIA 0- 12 TAHUN DI RS X KEBUMEN JAWA TENGAH
}

\author{
CHARACTERISTICS OF URINARY TRACT INFECTION IN CHILDREN AGES 0-12 \\ YEARS IN X HOSPITAL KEBUMEN CENTRAL OF JAVA
}

\author{
Agus Tusino ${ }^{1}$, Niken Widyaningsih ${ }^{2}$ \\ ${ }^{1}$ Departemen Ilmu Kesehatan Anak, \\ RSUD Kebumen-Fakultas Kedokteran, Universitas Islam Indonesia \\ ${ }^{2}$ Staf pada Fakultas Kedokteran, Universitas Islam Indonesia \\ Korespondensi: Agus Tusino. Email: agustosee@yahoo.com
}

\begin{abstract}
ABSTRAK
Infeksi saluran kemih merupakan penyakit yang sering ditemui pada anak-anak dan ditandai dengan jumlah bakteri yang bermakna dalam urin. Insidensi ISK masih tinggi, merupakan penyebab kedua morbiditas penyakit infeksi pada anak-anak setelah infeksi saluran napas. Di Indonesia, dari 200 anak yang dievaluasi sebesar 35\% pada anak 1-5 tahun dan 22\% anak usia 6-10 tahun menderita infeksi saluran kemih atau sekitar 33\% pada lakilaki dan 67\% pada perempuan. Metode Penelitian: Penelitin ini menunjukkan karakteristik infeksi saluran kemih pada anak usia 0-12 tahun di RS X Kebumen Jawa Tengah. Penelitian ini menggunakan desain penelitian crosssectional yang diperoleh dari catatan rekam medis pada periode September 2015 sampai September 2016. Hasil: Pada penelitian ini didapatkan 36 pasien anak dengan infeksi saluran kemih, 53\% laki-laki, 47\% perempuan dengan rentang usia terbanyak 5-12 tahun. Sebanyak 26 pasien dengan suhu $<38^{\circ} \mathrm{C}$, 3pasien dengan kelaianan anatomi, 3 pasien dengan riwayat infeksi saluran kemih sebelumnya, 15 pasien dengan gejala muntah, $41 \%$ pasien dengan leukopenia, $9 \%$ pasien dengan piuria, 14\% pasien dengan bakteriuria, 22 pasien mendapat terapi antibiotik golongan sefalosporin, dan 3 pasien menjalani terapi pembedahan. Kesimpulan: Infeksi saluran kemih terbanyak pada usia 5-12 tahun. Gejala klinis terutama muntah. Hasil urinalisis normal tidak menyingkirkan diagnosis infeksi saluran kemih, sehingga anak muntah usia 2 bulan sampai 12 tahun dengan penyebab tidak jelas perlu dipikirkan infeksi saluran kemih.
\end{abstract}

Kata Kunci: Karakteristik, Infeksi Saluran Kemih, Anak

\begin{abstract}
Urinary tract infection is a disease that is common in children and is characterized by a significant number of bacteria in the urine. UTI incidence is still high, is the second leading cause of infectious disease morbidity in children after respiratory tract infection. In Indonesia, 200 children were evaluated by 35\% in children 1-5 years old and 22\% of children aged 6-10 years suffering from a urinary tract infection, or approximately 33\% in men and $67 \%$ in women. Methods: this experiment shows the characteristics of urinary tract infection in children aged 0-12 years in X hospital, Kebumen, Central Java. This study uses a cross-sectional study design obtained from the medical record in the period September 2015 to September 2016. Results: In this study, 36 pediatric patients with urinary tract infections, 53\% male, 47\% female with an age range most $5-12$ years old. A total of 26 patients with temperature $<38^{\circ} \mathrm{C}$, 3pasien with kelaianan anatomy, 3 patients with a history of urinary tract infection before, 15 patients with symptoms of vomiting, $41 \%$ of patients with leukopenia, $9 \%$ of patients with pyuria, $14 \%$ of patients with bacteriuria, 22 patients cephalosporin class of antibiotic therapy, and 3 patients underwent surgical treatment. Conclusions: Urinary tract infections are the most at the age of 5-12 years. Clinical symptoms, especially vomiting. Normal urinalysis results do not exclude the diagnosis of urinary tract infection, so that the child vomits aged 2 months to 12 years with no obvious cause of urinary tract infections should be considered.
\end{abstract}

Keywords: Characteristics, Urinary Tract Infection, Children 


\section{PENDAHULUAN}

Infeksi saluran kemih merupakan penyakit yang sering ditemui pada anak-anak dan ditandai dengan jumlah bakteri yang bermakna dalam urin. Insidensi ISK masih tinggi, merupakan penyebab kedua morbiditas penyakit infeksi pada anakanak setelah infeksi saluran napas. Prevalensi ISK bervariasi bergantung pada usia dan jenis kelamin. Berkisar 3-10\% pada anak perempuan dan 1-3\% pada anak laki-laki (Subandiyah, 2015). Risiko ISK selama dekade pertama setelah kelahiran adalah $1 \%$ pada lelaki dan $3 \%$ pada perempuan. Pada usia sekolah, 5\% anak perempuan dan hingga $0,5 \%$ anak lelaki mengalami setidaknya satu episode ISK. Insidens ISK ini berbeda untuk anak usia kurang dari 3 bulan yang lebih umum terjadi pada anak lelaki (Wahyudi, 2015). Angka kejadian ISK pada anak sering terjadi pada pasien dengan kelaianan anatomi dan fungsi dari saluran kemih (Hay et al, 2011).

Prevalensi infeksi saluran kemih bervariasi berdasarkan usia, jenis kelamin, ras, dan status sirkumsisi. Bayi laki-laki usia kurang dari 3 bulan yang belum di sirkumsisi dan bayi perempuan dibawah 1 tahun memiliki prevalensi tertinggi (Shaikh et al, 2008). Manifestasi ISK sangat bervariasi dan bergantung usia, mulai dengan asimtomatik hingga gejala yang berat, sehingga ISK sering tidak terdeteksi baik oleh tenaga medis maupun orangtua. Kesalahan dalam menegakkan diagnosis akan sangat merugikan, yang dapat menyebabkan kerusakan ginjal karena tidak diterapi atau anak menjalani pemeriksaan dan pengobatan yang tidak perlu (Pardede, 2011).

Di Indonesia, dari 200 anak yang dievaluasi sebesar $35 \%$ pada anak 1 sampai 5 tahun dan $22 \%$ anak usia 6 sampai 10 tahun menderita infeksi saluran kemih atau sekitar $33 \%$ pada laki-laki dan $67 \%$ pada perempuan. Data ini menunjukan infeksi saluran kemih merupakan infeksi dengan angka kejadian cukup tinggi.

Penelitian ini bertujuan untuk menentukan prevalensi dan karakteristik infeksi saluran kemih pada anak usia 0-12 tahun di RS X, Kebumen, Jawa Tengah untuk pencegahan dan pengendalian infeksi saluran kemih pada anak.

\section{METODE}

Penelitian ini merupakan penelitian noneksperimental deskriptif. Penelitian dilakukan di
RS dr. Soedirman Kebumen pada bulan November 2016. Penelitian sudah mendapatkan ijin dari Komite Etik FK UII untuk aspek etika dan kepada Direktur RS X Kebumen untuk mengambil datadata yang diperlukan.

Sampel penelitian ini pasien anak usia 0-12 tahun rawat inap dan rawat jalan dengan diagnosis utama atau diagnosis tambahan infeksi saluran kemih di RS X Kebumen September 2015 sampai September 2016. Pasien anak yang didiagnosa infeksi saluran kemih tetapi tidak memiliki pemeriksaan urinalisis dieksklusikan dari penelitian. Sampel penelitian dihitung dengan rumus besar sampel. Didapatkan besar sampel sebanyak 34 sampel.

Variabel-variabel yang dilihat adalah faktor risiko infeksi saluran kemih pada anak (usia, jenis kelamin, sirkumsisi, riwayat konstipasi, kelainan anatomi, riwayat ISK sebelumya), gejala klinis (demam, kencing tidak lancar, nyeri saat berkemih, nafsu makan menurun, mual, muntah), pemeriksaan fisik (suhu), pemeriksaan penunjang (darah tepi, urinalisis, fungsi ginjal), pengobatan. Data masing-masing variabel didapatkan dari data sekunder (rekam medis dan dokumen) dari RS dr. Soedirman Kebumen. Data yang diperoleh dianalisis dan disajikan dalam bentuk diagram distribusi frekuensi untuk masing-masing variabel.

\section{HASIL DAN PEMBAHASAN}

Penelitian yang dilakukan di RS $X$ Kebumen, didapatkan 54 pasien infeksi saluran kemih, dari keseluruhan sampel, 18 diantaranya telah dieksklusi kerena tidak dilakukan pemeriksaan urinalisa, sehingga total sampel yang didapatkan oleh peneliti sebanyak 36 pasien infeksi saluran kemih.

Jumlah subjek penelitian 36 pasien dengan sebaran laki-laki 19 orang, sedangkan perempuan 17 orang pasien. Tidak terdapat pasien infeksi saluran kemih usia 2 bulan-1 tahun baik laki-laki maupun perempuan. Pasien infeksi saluran kemih usia 1-2 tahun berjenis kelamin laki-laki 2 orang dan 1 orang perempuan. Pasien infeksi saluran kemih usia 2-5 tahun berjenis kelamin laki-laki 2 orang dan 4 orang perempuan. Sedangkan pasien usia 5-12 tahun berjenis kelamin laki-laki 15 orang dan 12 orang berjenis kelamin perempuan. 
Tabel 1 Karakteristik Subjek Penelitian

\begin{tabular}{ccc}
\hline Variabel & Jumlah & Persentase \\
\hline Jenis kelamin & & \\
Laki-laki & 19 & $53 \%$ \\
Perempuan & 17 & $47 \%$ \\
Usia & & \\
2 bulan-1 tahun & & \\
Laki-laki & 0 & $0 \%$ \\
Perempuan & 0 & $0 \%$ \\
1-2 tahun & & \\
Laki-laki & 2 & $5,53 \%$ \\
Perempuan & 1 & $2,77 \%$ \\
2-5 tahun & & \\
Laki-laki & 2 & $5,57 \%$ \\
Perempuan & 4 & $11,13 \%$ \\
5-12 tahun & & \\
Laki-laki & 15 & $41,67 \%$ \\
Perempuan & 12 & $33,33 \%$ \\
\hline
\end{tabular}

Pada penelitian ini sebagian besar pasien tidak mengalami peningkatan suhu tubuh (demam). Hanya 10 pasien yang mengalami demam dan 26 lainnya tidak. Terdapat 3 pasien infeksi saluran kemih dengan faktor risiko kelainan anatomi. Riwayat infeksi saluran kemih sebelumnya menjadi salah satu penyebab infeksi saluran kemih berulang pada 3 pasien dalam penelitian ini.

Manifestasi klinis yang banyak muncul pada pasien infeksi saluran kemih pada penelitian ini diantaranya terdapat 2 pasien infeksi saluran kemih dengan manifestasi buang air kecil tidak lancar, terdapat 2 pasien infeksi saluran kemih dengan manifestasi nyeri saat buang air kecil, terdapat 2 pasien infeksi saluran kemih dengan manifestasi nafsu makan menurun, terdapat 8 pasien infeksi saluran kemih dengan manifestasi mual, terdapat 15 pasien infeksi saluran kemih dengan manifestasi muntah, dan terdapat 25 pasien infeksi saluran kemih dengan manifestasi lainnya berupa nyeri perut.

Pemeriksaan penunjang yang dilakukan pada pasien didapatkan hasil $41 \%$ pasien infeksi saluran kemih dengan jumlah leukosit dalam darah rendah, terdapat $30 \%$ pasien infeksi saluran kemih dengan jumlah leukosit dalam darah normal, dan terdapat $29 \%$ pasien infeksi saluran kemih dengan jumlah leukosit dalam darah tinggi. Sedangkan pada hasil urinalisa pasien infeksi saluran kemih pada penelitian ini didapatkan hanya $9 \%$ pasien dengan piuria dan $14 \%$ pasien dengan bakteriuria, sedangkan lainnya tidak terdeteksi adanya leukosit maupun bakteri dalam urin.

Pola pemberian antibiotik pada pasien infeksi saluran kemih anak dalam penelitian ini diantaranya golongan sefalosporin, golongan penisilin, dan golongan trimetoprim. Selain pemberian antibiotik, beberapa pasien mendapatkan terapi pembedahan. Terapi pembedahan merupakan salah satu terapi yang diberikan pada pasien infeksi saluran kemih pada penelitian ini. Terdapat 3 pasien yang memperoleh terapi pembedahan, 2 diantaranya dilakukan sirkumsisi dengan indikasi fimosis dan 1 pasien dilakukan tindakan reparasi hipospadia dengan indikasi hipospadia.

Penelitian yang dilakukan di RS X Kebumen ini membahas mengenai karakteristik infeksi saluran kemih pada anak. Berdasarkan penelitian ini, dari 36 pasien anak yang didiagnosis infeksi saluran kemih, 11 orang berjenis kelamin laki-laki, sedangkan 17 orang pasien berjenis kelamin perempuan. Hal ini menunjukkan bahwa tingkat kejadian infeksi saluran kemih anak lebih tinggi pada laki-laki daripada perempuan. Hal ini dapat disebabkan pada bayi atau anak laki-laki belum disirkumsisi terjadi peningkatan risiko infeksi saluran kemih lima sampai dua belas kali lipat (Marcdante et al., 2011). 


\begin{tabular}{|c|c|c|}
\hline Variabel & Jumlah & Persentase \\
\hline \multicolumn{3}{|l|}{ Suhu Tubuh } \\
\hline$<38^{\circ} \mathrm{C}$ & 26 & $72,22 \%$ \\
\hline $38-39^{\circ} \mathrm{C}$ & 6 & $16,67 \%$ \\
\hline$>38^{\circ} \mathrm{C}$ & 4 & $11,11 \%$ \\
\hline \multicolumn{3}{|l|}{ Faktor Risiko } \\
\hline Sirkumsisi & 0 & $0 \%$ \\
\hline Konstipasi & 0 & $0 \%$ \\
\hline Riwayat ISK & 3 & $8,33 \%$ \\
\hline Kelainan Anatomi & 3 & $8,33 \%$ \\
\hline Lainnya & 1 & $2,78 \%$ \\
\hline Tidak Ada Keterangan & 29 & $80,56 \%$ \\
\hline \multicolumn{3}{|l|}{ Manifestasi Klinis } \\
\hline BAK Tak Lancar & 2 & $5,56 \%$ \\
\hline Nyeri BAK & 2 & $5,56 \%$ \\
\hline Nafsu Makan Menurun & 2 & $5,56 \%$ \\
\hline Mual & 8 & $22,22 \%$ \\
\hline Muntah & 15 & $41,67 \%$ \\
\hline Lainnya & 25 & $69,44 \%$ \\
\hline \multicolumn{3}{|l|}{ Leukosit Darah } \\
\hline Rendah & 10 & $29 \%$ \\
\hline Normal & 11 & $30 \%$ \\
\hline Tinggi & 15 & $41 \%$ \\
\hline \multicolumn{3}{|l|}{ Leukosit Urin } \\
\hline Normal & 33 & $91 \%$ \\
\hline Meningkat & 3 & $9 \%$ \\
\hline \multicolumn{3}{|l|}{ Bakteri Urin } \\
\hline Positif & 5 & $14 \%$ \\
\hline Negatif & 31 & $86 \%$ \\
\hline \multicolumn{3}{|l|}{ Antibiotik } \\
\hline Gol. Trimetroprim & 1 & $2,78 \%$ \\
\hline Gol. Sefalosporin & 22 & $61,1 \%$ \\
\hline Gol. Penisilin & 13 & $36,1 \%$ \\
\hline \multicolumn{3}{|l|}{ Pembedahan } \\
\hline Ya & 3 & $8,33 \%$ \\
\hline Tidak & 33 & $91,67 \%$ \\
\hline
\end{tabular}

Pada penelitian ini tidak terdapat pasien infeksi saluran kemih berusia 2 bulan sampai 1 tahun, terdapat 3 pasien infeksi saluran kemih berusia 1-2 tahun, terdapat 7 pasien infeksi saluran kemih berusia 2-5 tahun, terdapat 27 pasien infeksi saluran kemih berusia 5-12 tahun.

Berdasarkan hasil perbandingan jenis kelamin pasien infeksi saluran kemih terhadap usia pada penelitian ini didapatkan: tidak terdapat pasien infeksi saluran kemih usia 2 bulan sampai 1 tahun baik berjenis kelamin laki-laki maupun perempuan. Pasien infeksi saluran kemih 1-2 tahun berjenis kelamin laki-laki 2 orang dan 1 orang berjenis kelamin perempuan. Pasien infeksi saluran kemih usia 2-5 tahun berjenis kelamin laki-laki 2 orang dan 4 orang berjenis kelamin perempuan. Sedangkan pasien infeksi saluran kemih usia 5-12 tahun berjenis kelamin laki-laki 15 orang dan 12 orang berjenis kelamin perempuan. Hal ini memiliki sedikit perbedaaan dengan penelitian yang dilakukan pada pasien infeksi saluran kemih di RSCM Jakarta tahun 2004. Pada penelitian tersebut diperoleh data terdapat 9 pasien infeksi saluran kemih berjenis kelamin laki-laki dan 8 pasien berjenis kelamin perempuan di usia 2 bulan sampai 1 tahun. Pasien infeksi saluran kemih usia 1-2 tahun berjenis kelamin laki-laki 7 orang dan 8 orang berjenis kelamin perempuan. Pasien infeksi saluran kemih usia 2-5 tahun berjenis kelamin laki-laki 10 orang dan 4 orang berjenis kelamin perempuan. Sedangkan pasien infeksi saluran kemih berusia diatas 5 tahun berjenis kelamin laki-laki 2 orang dan 12 orang berjenis kelamin perempuan. Prevalensi kejadian infeksi saluran kemih pada laki-laki di usia 2 bulan sampai2 tahun lebih tinggi daripada perempuan dapat dikarenakan pada anak usia tersebut belum dilakukan tindakan sirkumsisi, 
sehingga sisa urin pasca miksi dapat tertinggal di prepusium (Purnomo, 2012). Prevalensi kejadian infeksi saluran kemih pada laki-laki di usia dua tahun sampai lima tahun lebih rendah daripada perempuan dapat dikarenakan anatomi uretra antaralaki-laki dan perempuan berbeda. Panjang uretra perempuan kurang lebih $3-5 \mathrm{~cm}$, sedangkan pada laki-laki kurang lebih $23-25 \mathrm{~cm}$. Perbedaan inilah yang menyebabkan seringnya infeksi saluran kemih terjadi pada perempuan (Purnomo, 2012).

Sebagian besar pasien infeksi saluran kemih pada penelitian ini tidak mengalami peningkatan suhu tubuh (demam). Hanya 10 pasien yang mengalami demam dan 26 lainnya tidak.

Proses terjadinya demam dimulai dari stimulasi sel-sel darah putih (monosit, limfosist, dan neutrofil) oleh pirogen eksogen baik berupa toksin, mediator inflamasi, atau reaksi imun. Sel-sel darah putih tersebut akan mengeluarkan zat kimia yang dikenal dengan pirogen endogen (IL-1, IL6 , TNF- $\alpha$, dan IFN). Prostaglandin yang terbentuk kemudian akan meningkatkan patokan termostat di pusat termoregulasi di hipotalamus. Hipotalamus akan menganggap suhu sekarang lebih rendah dari suhu patokan yang baru sehingga ini memicu mekanism-mekanisme untuk meningkatkan panas antara lain menggigil, vasokonstriksi kulit, dan mekanisme volunter seprti memakai selimut. Sehingga akan terjadi peningkatan produksi panas dan penurunan penggunaan panas yang pada akhirnya akan menyebabkan suhu tubuh naik ke patokan yang baru tersebut (Sherwood, 2014).

Pada penelitian ini terdapat 3 pasien infeksi saluran kemih dengan faktor risiko kelainan anatomi. Obstruksi adalah salah satu penyebab paling umum dari infeksi saluran kemih. Fimosis dapat mempengaruhi infeksi aluran kemih. Enterobakteria yang diperoleh dari flora normal prepusium, permukaan glandular, dan distal uretra. E. coli dapat mengekspresikan $\mathrm{P}$ fimbriae, yang melekat ke lapisan dalam dari kulit preputium dan ke sel uroepitelial. Berbagai abnormalitas kongenital saluran kemih bisa menyebabkan infeksi saluran kemih akibat obstruksi, seperti katup uretra posterior dan ureteropelvic junction obstruction. Adanya statis urin yang nonobstruktif, seperti sindrom prune belly dan VUR juga dapat menyebabkan infeksi saluran kemih. Penyebab infeksi saluran kemih lain yang cukup sering dan signifikan adalah adhesi labia (Wahyudi,
2015). Fimosis menyebabkan gangguan aliran urin berupa sulit kencing, pancaran urin mengecil, menggembungnya ujung prepusium penis saat miksi, dan menimbulkan retensi urin. Higiene lokal yang kurang bersih menyebabkan terjadinya infeksi saluran kemih (Purnomo, 2011).

Riwayat infeksi saluran kemih sebelumnya menjadi salah satu penyebab infeksi saluran kemih berulang pada 3 pasien dalam penelitian ini. Rekurensi infeksi saluran kemih dapat terjadi pada sepetiga hingga setengah pasien anak yang mengalami infeksi saluran kemih. Beberapa hal yang dapat menjadi pencetus infeksi saluran kemih berulang pada pasien diantaranya: pertumbuhan bakteri pada urogenital, prepusim memfasilitasi pertumbuhan bakteri perimeatal, adhesi bakteri ke sel uroepitelial, flora normal memfasilitasi pertumbuhan urobakteri patogen, kurangnya sekresi sitokin urotelial, stasis urin, dan refluks vesikouretra (Tewary \& Narchi, 2015).

Pada penelitian ini terdapat 2 pasien infeksi saluran kemih dengan manifestasi buang air kecil tidak lancar, terdapat 2 pasien infeksi saluran kemih dengan manifestasi nyeri saat buang air kecil, terdapat 2 pasien infeksi saluran kemih dengan manifestasi nafsu makan menurun, terdapat 8 pasien infeksi saluran kemih dengan manifestasi mual, terdapat 15 pasien infeksi saluran kemih dengan manifestasi muntah, dan terdapat 25 pasien infeksi saluran kemih dengan manifestasi lainnya berupa nyeri perut. Hasil penelitian ini memiliki kemiripan dengan penelitian yang dilakukan di Departemen Ilmu Kesehatan Anak RS Y Jakarta pada bulan Februari-Agustus 2004. Pada penelitian tersebut diperoleh 28 pasien dengan keluhan nafsu makan menurun, 21 pasien dengan keluhan diare, 17 pasien dengan kencing tidak lancar, 15 pasien dengan muntah, 12 pasien dengan mual, 10 pasien dengan menangis jika berkemih, 10 pasien dengan cengeng, 4 pasien dengan sering berkemih, 2 pasien dengan keluhan konstipasi, dan 1 pasien dengan keluhan inkontinensia urin.

Pada penelitian ini terdapat $41 \%$ pasien infeksi saluran kemih dengan jumlah leukosit dalam darah rendah, terdapat $30 \%$ pasien infeksi saluran kemih dengan jumlah leukosit dalam darah normal, dan terdapat $29 \%$ pasien infeksi saluran kemih dengan jumlah leukosit dalam darah tinggi.

Berdasarkan hasil urinalisa pasien infeksi saluran kemih pada penelitian ini didapatkan hanya $9 \%$ pasien dengan piuria dan $14 \%$ pasien dengan 
bakteriuria, sedangkan lainnya tidak terdeteksi adanya leukosit maupun bakteri dalam urin. Temuan positif piuria dan bakteriuria yang relatif sedikit ini sesuai dengan penelitian yang dilakukan pada pasien anak di RS Y Jakarta pada tahun 2004. Pada penelitian tersebut didadapatkan pasien dengan piuria 11/50 dan bakteriuria 6/50. Menurut Association of America Pedriatrics (AAP) terdapat rentang yang luas pada laporan hasil urinalisa. Hasil urinalisa negatif tidak dapat menyingkirkan kemungkinan diagnosis infeksi saluran kemih, karena hasil urinalisa sangat dipengaruhi oleh valume urin, kecepatan, dan lamanya urin diputar serta keterampilan petugas. Hasil urinalisa terbaik didapatkan jika dikerjakan oleh petugas yang terampil pada urin segar (dikerjakan sekitar 3060 menit sesudah urin tertampung) dan dilakukan kombinasi pemeriksaan esterase leukosit, nitrit, dan pemeriksaan leukosit urin serta pewarnaan gram dengan menggunakan mikroskop (Santen SA et al., 2001).

Adanya piuria ( $>5$ leukosit per lapang pandang besar) dan bakteriuria dalam sampel urin memperkuat diagnosis klinis ISK (Watson, 2004). Bakteriuria tanpa piuria ditemukan pada $0,5 \%$ spesimen. Angka ini berkorelasi dengan kejadian bakteriuria simtomatik pada masa kanak-kanak. Bakteriuria tanpa piuria bisa jadi akan ditemukan jika terdapat kontaminasi bakteri, kolonisasi (bakteriuria asimptomatik), ketika mengumpulkan sebuah spesimen sebelum ada gejala dari reaksi inflamasi. Oleh karena itu, parameter bakteriuria ataupun piuria saja kurang dapat menjadi parameter yang terpercaya untuk mendiagnosis ISK. Pemeriksaan dapat dipengaruhi oleh faktor lain, seperti misalnya tingkatan hidrasi, cara pengumpulan spesimen, sentrifugasi, volume dimana sedimen disuspensi dan interpretasi subyektif terhadap hasil. Guideline Penatalaksanaan Infeksi Saluran Kemih dan Genitalia Pria 2015, 47 Pada neonatus dan anak usia kurang dari 6 bulan, baik piuria, bakteriuria ataupun uji nitrit, secara terpisah kurang memiliki nilai prediktif untuk ISK. Sebaliknya, nilai prediktif positif dari pewarnaan gram pada piuria adalah $85 \%$. Pada anak yang lebih tua, piuria dengan uji nitrit positif akan lebih terpercaya untuk didiagnosis ISK, dengan nilai prediktif positif $98 \%$. Mengkombinasikan bakteriuria dan piuria pada anak dengan febris, hasilnya $\geq 10$ $\mathrm{WBC} / \mathrm{mm} 3$ dan $\geq 50,000 \mathrm{cfu} / \mathrm{mL}$ pada sebuah spesimen yang dikumpulkan dengan kateterisasi termasuk signifikan untuk sebuah ISK, dan dapat membedakan antara infeksi dan kontaminasi (Wahyudi, 2015).

Penelitian ini juga mengamati pola pemberian antibiotik pada pasien infeksi saluran kemih anak. Berdasarkan hasil penelitian, antibiotik yang banyak diberikan pada pasien infeksi saluran kemih anak diantaranya golongan sefalosporin, golongan penisilin, dan golongan trimetoprim. Hal ini sesuai dengan guideline pentalaksanaan infeksi saluran kemih yang menyatakan pengobatan oral yang direkomendasikan adalah dengan TMP, Sefalosporin oral atau Amoksisilin /Asam Klavulanat, dengan tetap menyesuaikan dengan pola resistensi kuman (Wahyudi, 2015). Kunci dalam manajemen infeksi aluran kemih adalah diagnosis dini dan inisiasi antibiotik yang tepat. Beberapa faktor yang harus dipertimbangkan dalam pemilihan dan cara pemberian antibiotik empirik diantaranya usia pasien, tingkat keparahan klinis, lokasi infeksi, adanya komplikasi, dan pola prevalensi resistensi antibiotik.

Antibiotik golongan Sefalosporin dan golongan Penisilin memiliki mekanisme kerja penghambatan pada sitesis peptidoglikan dinding sel bakteri. Biosintesis peptidoglikan melibatkan sekitar 30 enzim bakteri dan dapat dinyatakan dalah tiga tahap. Tahap pertama adalah pembentukan prekursor yang terjadi dalam sitoplasma menghasilkan uridin dipospat (UDP)asetilmuramil-penta peptida. Selama reaksi tahap kedua, UDP asetilmuramil-penta peptida tersambung membentuk polimer panjang. Pada tahap ketiga dan tahap akhir, terjadi penyelesaiin ikatan silang. Hal ini tercapai melalui reaksi transpeptidasi yang terjadi di luar membran sel. Penghambatan transpeptidase menyebabkan pembentukan sferoplast dan lisis yang cepat (Petri W., 2008). Antibiotik golongan Trimetoprim mencegah reduksi dihidrofilat $\left(\mathrm{FAH}_{2}\right)$ dengan cara berikatan dan menghambat reduktase dihidrofolat (Olson J., 2004). Pengobatan infeksi saluran kemih bagian bawah tanpa komplikasi dengan menggunakan Trimetoprim-Sulfametosazol sering kali sangat efektif untuk bakteri yang peka. Sediaan ini terbukti menghasilkan efek terapi yang lebih baik daripada pemberian masing-masing komponennya secara terpisah jika mikroorganisme penginfeksinya merupaka famili Enterobacteriaceae. Terapi dosis tunggal (320 mg 
trimetoprim ditambah $160 \mathrm{mg}$ sulfometokxazol) efektif pada beberapa kasus pengobatan infeksi saluran kemih akut tanpa komplikasi, namun terapi minimal tiga hari kemungkinan lebih efektif (Petri W., 2008).

Terapi pembedahan merupakan salah satu terapi yang diberikan pada pasien infeksi saluran kemih pada penelitian ini. Terdapat 3 pasien yang memperoleh terapi pembedahan, 2 diantaranya dilakukan sirkumsisi dengan indikasi fimosis dan 1 pasien dilakukan tindakan reparasi hipospadia dengan indikasi hipospadia.

Sirkumsisi merupakan tindakan membuang prepusium penis sehingga glans penis menjadi terbuka. Tindakan ini merupakan tindakan bedah minor yang paling banyak dikerjakan di seluruh dunia, baik dikerjakan oleh dokter, para medis, maupun dukun sunat. Sirkumsisi secara medis bertujuan untuk menjaga higiene penis dari smegma dan sisa-sisa urin, mencegah terjadinya infeksi pada glans atau prepusium penis, dan mencegah timbulnya karsinoma penis (Purnomo, 2012). Pada meta-analisis 22 penelitian didapatkan hasil bahwa laki-laki yang tidak dilakukan sirkumsisi memiliki risiko terkena infeksi saluran kemih sebesar 32,1\% (Morris \& Wiswell, 2013). Kolonisasi bakteri pada prepusium dapat diturunkan dengan sirkumsisi, hal ini telah diteliti di berbagai negara baik di
Eropa, Amerika, maupun Asia (Kanematsu, 2016).

Reparasi hipospadia bertujuan untuk: kosmetik penis sehingga fungsi miksi dan fungsi seksual normal (ereksi lurus dan pancaran ejakulasi kuat) dan penis dapat tumbuh dengan normal. Reparasi hipospadia dianjurkan pada usia pra-sekolah agar tidak mengganggu proses belajar pada saat opersi. Perlu diingat bahwa sering kali rekonstruksi hipospadia membutuhkan lebih dari sekali operasi, koreksi ulang jika terjadi komplikasi. Pada hipospasia posterior dengan disertai testis maldesensus dianjurkan untuk melakukan uretroskopi praoperasi guna melihat kemungkinan adanya pembesaran atrikulus prostatikus yang mungkin terdapat keraguan jenis kelamin. Penyulit yang dapat terjadi setelah operasi hipospadia adalah fistula uretrokutan, stensis meatus uretra, sikatrik uretra, korde yang belum sepenuhnya terkoreksi, dan timbulnya divertikel uretra (Purnomo, 2012).

\section{SIMPULAN}

Infeksi saluran kemih terbanyak pada usia 5-12 tahun. Hasil urinalisis normal tidak meningkirkan diagnosis infeksi saluran kemih, sehingga anak muntah usia 2 bulan sampai 12 tahun dengan penyebab tidak jelas perlu dipikirkan kemungkinan infeksi saluran kemih

\section{DAFTAR PUSTAKA}

Hay William W, 2011. Current Diagnosis \& Treatment Pediatri $20^{\text {th }}$ Ed. USA

Kanematsu Akihiro, 2016. Review Article: Management of Phimosis as a Risk Factor of Urinary Tract Infection: An Asian Perspective. Urological Sience

Marcdante et al., 2011. Nelson Ilmu Kesehatan Anak Esensial Edisi Keenam. Singapura: Elsevier

Morris Brian J., 2013. Circumcision and Lifetime Risk of Urinary Tract Infection : A Systematic Review and Meta-Analysis. The Journal of Urology, Vol 189 (6):2118-2124

Nijman J.M., Butler R., Gool J.V., 2000. Conservative Management of Urinary Incontinence in Childhood. Journal of Paediatric Urology 2000:513-51

Olson J., 2004. Belajar Mudah Farmakologi. Jakarta: EGC

Pardede S.O., 2011. Konsensus Infeksi Saluran Kemih pada Anak. Jakarta

Purnomo B., 2012. Dasar-Dasar Urologi Edisi Ketiga. Jakarta: Sagung Seto

Petri W., 2008. Dasar Farmakologi Terapi Vol 2. Jakarta: EGC

Santen SA ., 2001. Pedriatric Urinary Tract Infection. Emerg Med Clin Nort Am 19:675-90

Subandiyah Krisni, 2015. Gangguan Berkemih pada Anak. Surabaya: Airlangga University Press

Shaikh., 2008. Prevalence of Urinary Tract Infection in Childhood : A Meta-Analysis. The Pedriatric Infection Disease Journal, Volume 27, Issue 4, pp 302-308 
Tewary K., Narchi H., 2015. Recurrent Urinary Tract Infection in Children : Preventive Intervention Other than Prophylactic Antibiotics. World Journal of Methodology 5 (2): 13-19

Sherwood L., 2014. Fisiologi Manusia. Jakarta: EGC

Wahyudi Irfan, 2015. Guideline Penatalaksanaan Infeksi Saluran Kemih dan Genitalia Pria 2015: Infeksi Saluran Kemih pada Anak. Jakarta: IAUI

Watson A.R., 2004. Pediatric Urinary Tract Infection. EAU Update Series. 2(3): p. 94-100 